\title{
PENGEMBANGAN BAHAN AJAR KOSMOGRAFI BERBASIS AL QURAN UNTUK MENINGKATKAN KECERDASANSPIRITUAL MAHASISWA
}

\author{
Furqan Ishak Aksa, Ramdan Afrian, Hartutik
}

Masuk: 07112017 / Diterima: 30122017 / Dipublikasi: 31122017

(c) 2017Fakultas Hukum dan IImu Sosial UNDIKSHA dan IGI

\begin{abstract}
This research is based on the dryness of spiritual values in cosmographic learning in college. This is because of the cosmographic material currently available contains only the cognitive domain. This condition makes the learning of cosmography in college did not succeed in making the students as a person who glorifies God and pious in accordance with the mandate of Law No. 12 of 2012. This study aims to develop cosmographic teaching materials by integrating Qur'anic verses. The research procedure is done by modifying the Dick and Carey model which is done through 7 stages. The results showed that the acceptance of teaching materials products reached $80,42 \%$. An important finding of this research is the integration of Qur'anic verses into teaching material can add the belief of the respondent to God Almighty for the creation of the universe. This makes the student become a person who glorifies God. Although spiritual intelligence is difficult to measure with various instruments, but at least the opinions of most respondents, it can be used as a benchmark that learning Al Quran-based cosmography can increase students' confidence in God Almighty.
\end{abstract}

Key words: Cosmographic Material, Based on Al Quran, Spiritual Intelligence.

Abstrak Penelitian ini didasari masalah keringnya nilai spiritual dalam pembelajaran kosmografi di perguruan tinggi. Hal ini disebabkan bahan ajar kosmografi yang tersedia saat ini hanya mengandung ranah kognitif. Kondisi ini membuat pembelajaran kosmografi di perguruan tinggi tidak berhasil menjadikan mahasiswa sebagai pribadi yang mengagungkan Tuhan dan bertaqwa sesuai dengan amanat Undang Undang Nomor 12 Tahun 2012. Penelitian ini bertujuan untuk mengembangkan bahan ajar kosmografi dengan mengintegrasikan ayat $\mathrm{Al}$ Quran. Prosedur penelitian dilakukan dengan memodifikasi model Dick and Carey yang dilakukan melalui 7 tahap. Hasil penelitian menunjukkan tingkat penerimaan produk bahan ajar mencapai 80, 42 \%. Temuan penting dari penelitian ini adalah integrasi ayat Al Quran ke dalam bahan ajar dapat menambah keyakinan responden kepada Tuhan Yang Maha Esa atas penciptaan alam semesta. Hal ini membuat mahasiswa menjadi pribadi yang mengagungkan Tuhan. Meskipun kecerdasan spiritual sulit diukur dengan berbagai instrument, namun paling tidak pendapat sebagian besar responden, dapat dijadikan tolak ukur bahwa pembelajaran kosmografi berbasis Al Quran dapat meningkatkan keyakinan mahasiswa kepada Tuhan Yang Maha Esa.

Kata kunci : Bahan Ajar Kosmografi, Berbasis Al Quran, Kecerdasan Spiritual.

\section{Pendahuluan}

Pendidikan tinggi bertujuan men-gembangkan potensi peserta didik

Furqan Ishak Aksa ${ }^{1}$, Ramdan Afrian ${ }^{1}$, dan Hartutik ${ }^{2}$ ${ }^{1}$ Program Studi Pendidikan Geografi,

furqanishaksa@unsam.ac.id

${ }^{2}$ Program Studi Pendidikan Sejarah, FKIP Universitas Samudra, Aceh agar menjadi manusia yang beriman dan ber-takwa kepada Tuhan Yang Maha Esa, berakhlak mulia, sehat, berilmu, cakap, kreatif, mandiri, dan menjadi warga negara yang demokratis serta bertanggung jawab (Undang 
Undang Nomor 12 Tahun 2012). Tujuan mulia tersebut dapat terwujud apabila pendidikan di perguruan tinggi dilaksanakan secara menyeluruh. Tidak hanya mendidik intelektual dan keterampilan mahasiswa. Namun menyentuh ranah spiritual.

Pembelajaran komprehensif yang mengintegrasikan kemampuan kognitif, keterampilan, dan sikap tidak dapat terwujud tanpa adanya bahan ajar yang mengandung tiga aspek tersebut. Hal ini dikarenakan bahan ajar memiliki peran penting dalam mencapai tujuan pem-belajaran (Aksa, 2016 ; Purwanto, 2001).

Bahan ajar berperan sebagai aplikasi kongkrit dari kurikulum (Astawa, 2013; Lee \& Catling, 2016). Hal ini menyebabkan bahan ajar dijadikan komponen utama dalam mencapai tujuan pembelajaran (Mahmood, 2011). Oleh karena itu, keberadaan bahan ajar yang baik (berkualitas) tentu sangat penting guna mencapai tujuan pembelajaran di perguruan tinggi.

Buku ajar yang baik, paling tidak mengandung tiga asepk di dalamnya, meliputi : kognitif, keterampilan, dan sikap. Aspek kognitif menekankan pada peran bahan ajar harus mampu mengembang-kan intelegensi mahasiswa sedangkan bidang sikap, bahan ajar harus mampu mengembangkan keterampilan berkomunikasi di dalam kelompok sosial, dan dari segi sikap, bahan ajar harus mampu mengembangkan pemahaman tentang norma dan nilai (Seefeldt, 1993).

Namun demikian, kondisi di lapangan menunjukkan bahwa bahan ajar yang mengintegrasikan ketiga aspek tersebut sangat jarang ditemukan. Hal ini dibuktikan dari hasil analisis terhadap buku ajar yang digunakan oleh dosen dan mahasiswa di beberapa perguruan tinggi di Provinsi Aceh. Sebagian besar konten (isi) bahan ajar di perguruan tinggi hanya menyentuh ranah kognitif. Salah satunya bahan ajar kosmografi yang digunakan oleh dosen dan mahasiswa pada program studi pendidikan geografi.

Kondisi tersebut membuat pembelajaran kosmografi di perguruan tinggi tidak berhasil menjadikan mahasiswa sebagai pribadi yang bertakwa kepada Tuhan Yang Maha Esa. Pembelajaran kosmografi kering nilainilai spiritual. Kajian tentang alam semesta hanya didasari oleh teori yang dikemukakan oleh para ahli. Hal ini tentu bertentangan dengan tujuan pendidikan tinggi yang diamanatkan dalam undang-undang.

Berdasarkan permasalahan tersebut, perlu dikembangkan bahan ajar yang mengintegrasikan kognitif, keterampilan, dan nilai. Salah satu upaya yang dapat dilakukan untuk meng-itegrasikan nilai karakter kepada mahasiswa adalah dengan menyisipkan kandungan Al Quran ke dalam bahan ajar kosmografi. Hal ini dikarenakan, Al Quran membahas semua aspek kehidupan manusia, termasuk misteri tentang alam semesta (Abdushshamad, 2003; Murtono, 2015; Sani, 2015).

Dalam Al Quran banyak ayat dan surah yang menjelaskan tentang alam semesta, misalnya tentang teori big bang yang mengemukakan bahwa seluruh alam semesta awalnya adalah sebuah masa yang sangat besar. 
Kemudian, terjadilah ledakan besar "big bang" yang membentuk galaksi yang terdiri dari bintang, planet, bulan serta benda langit lainnya (Abdushshamad, 2003; Al-Khader, 2001).

Merujuk pada Al-Quran, ada beberapa ayat yang menjelaskan tentang terjadinya alam semesta, yakni dalam surah Al-An'am ayat 6 "Dialah pencipta langit dan bumi", kemudian dalam Q.S Al Anbiyaa: 30 "Dan apakah orang-orang yang kafir tidak mengetahui bahwasanya langit dan bumi itu keduanya dahulu adalah suatu yang padu, kemudian kami pisahkan antara keduanya. Dan dari air kami jadikan segala sesuatu yang hidup. Maka mengapakah mereka tiada juga beriman?".

Dari beberapa ayat di atas secara eksplisit dapat disimpulkan bahwa alam semesta ini pada awalnya merupakan suatu yang padu. Keterangan dari AI-Quran tersebut sesuai dengan temuan ilmiah yang pernah dikemukakan oleh Abbe Lemaitre pada tahun 1920 yang menyatakan bahwa alam semesta bermula dari gumpalan super atom raksasa suhunya 10 miliar sampai 1 triliun derajat celcius (Eicher, 2015). Gumpalan super atom tersebut meledak sekitar 15 milyar tahun yang lalu dan hasil dentuman menyebar menjadi debu dan awan hidrogen. Setelah berumur ratusan juta tahun, debu dan awan hidrogen tersebut membentuk bintang-bintang dengan ukuran yang berbeda. Kumpulan bintang tersebut membentuk galaksi yang teratur. (Manzil dalam Yani, 2014).

Di samping itu, temuan para ilmuan yang menyatakan bahwa alam semesta mengembang secara terus menerus sejak terjadinya "ledakan" juga telah diterangkan dalam AI Quran. Dalam surat Adh-Dhariyat : 51 "Dan langit itu kami bangun dengan kekuasaan kami dan sesungguhnya kami benar-benar meluaskannya". Mengembangnya alam semesta seperti yang dijelaskan dalam ayat tersebut, telah dibuktikan oleh astronom Amerika bernama Edwin Hubble. Setelah melakukan pengamatan terhadap galaksi yang ada di jagad raya, Hubble menyimpulkan bahwa panjang gelombang galaksi di jagad raya terus mengalami pergeseran (Eicher, 2015). Akhirnya, Hubble menyimpulkan bahwa semua galaksi saling menjauh dari titik awalnya. Hal ini dapat dikatakan bahwa alam semesta tidak tetap melainkan mengembang (Al-Khader, 2001; Murtono, 2005). Pemuaian alam semesta ini akan terus berlangsung sampai hilangnya gaya gravitasi bendabenda langit tersebut.

Penjelasan dari surah dan ayat dalam Al Quran di atas tentang alam semesta hanya sebagian kecil yang diuraikan. Secara keseluruhan, paling tidak terdapat 463 ayat yang menjelaskan tentang alam semesta beserta seluruh isinya (Abdushshamad, 2003). Oleh karena itu, sebagai mata kuliah yang bertujuan menjadikan mahasiswa memiliki pengetahuan tentang alam semesta dan pengaruhnya terhadap aktivitas makhluk hidup di permukaan bumi serta menjadikan mahasiswa menyadari akan kebesaran Tuhan yang telah menciptkan alam semesta, mengintegrasikan ayat AI-Quran pada bahan ajar kosmografi tentu sangat penting untuk dilakukan. Hal ini 
dimaksudkan untuk mencapai tujuan pembelajaran kosmografi seperti yang dituangkan dalam Rencanan Pembelajaran Semester (RPS) yang dikembangkan di berbagai perguruan tinggi di Indonesia.

Dalam rangka mencapai tujuan pembelajaran tersebut, tentu banyak motode yang dapat dilakukan. Misalnya, dalam ranah kognitif dan keterampilan, pembelajaran dapat dikembangkan dnengan menerapkan model pembelajaran inquiry dan Project Based Learning (PBL). Model-model pembelajaran tersebut sangat efektif untuk merangsang kognitif mahasiswa untuk berfikir kritis dan kreatif (Lee \& Catling, 2016).

Di samping itu, untuk mencapai tujuan pembelajaran dari aspek sikap, nilai-nilai yang terkandung dalam AlQuran sangat efektif untuk diintegrasikan dalam bahan ajar. Ayatayat Al-Quran yang disisipkan dalam bahan ajar dapat meningkatkan keimanan dan ketaqwaan pembaca kepada sang pencipta. Hal ini membuat pembelajaran kosmografi lebih bermakna. Kebenaran-kebenaran AlQuran yang disisipkan dalam bahan ajar kosmografi dapat menjadi bahan tafakkur mahasiswa kepada Tuhannya.

Selain itu, pembelajaran kosmografi tidak dapat dipisahkan dari kajian agama. Hal ini dikarenakan banyak sekali misteri alam semesta yang belum terpecahkan oleh ilmuan dewasa ini. Misalnya tentang adanya kehidupan lain selain di bumi. Sampai saat ini para ilmuan masih terus melakukan penelitian terhadap kehidupan di planet yang terdapat di gugusan milky way. Salah satunya adalah ekspedisi ke planet mars. Planet merah tersebut dipilih karena hasil penelitian ditemukan bahwa proses pembentukan dan evolusinya hampir sama dengan sejarah pembentukan bumi. Namun demikian, hasil penelitian ditemukan bahwa planet mars memiliki atmosfer yang sangat tipis sehingga tidak dapat melindungi mars dari hujan meteor dan radiasi matahari secara langsung. Hal ini yang menyebabkan planet tersebut tidak dapat dihuni oleh makhluk hidup. Apabila merujuk pada Al Quran secara tersurat telah dijelaskan dalam surah An Naml ayat 61 yang artinya: "atau siapakah yang telah menjadikan bumi sebagai tempat berdiam, dan yang menjadikan sungai-sungai di celahcelahnya, dan yang menjadikan gunung-gunung untuk (mengkokohkan)nya dan menjadikan suatu pemisah antara dua laut? Apakah disamping Allah ada Tuhan (yang lain)? bahkan (sebenarnya) kebanyakan dari mereka tidak mengetahui". Ayat tersebut secara jelas menyebutkan bahwa bumi adalah tempat berdiam. Menurut Al Quran tidak ada kehidupan lain selain di bumi. Hal ini dikarenakan tidak ada satu ayat pun yang menjelaskan tentang kehidupan di planet lain.

Berdasarkan fakta tersebut, sangat penting untuk dilakukan penggalian ilmiah yang terkadung dalam kitab-kitab samawi (Sahifab Ibrahim dan Nuh, Taurat, Injil, dan alQuran) yang diturunkan Tuhan kepada umat manusia. Hal ini dikarenakan kitab-kitab tersebut mengandung mukjizat ilmiah yang tersirat maupun tersurat tentang pembentukan alam semesta serta rahasia planet bumi. Hal ini sangat membantu para ilmuan 
dalam mengungkap misteri alam semesta ini.

\section{Metode}

Penelitian ini menggunakan desain penelitan dan pengembangan. Prosedur pengembangan dilakukan dengan me-modifikasi model Dick and Carey yang dilakukan melalui tujuh tahap berikut:

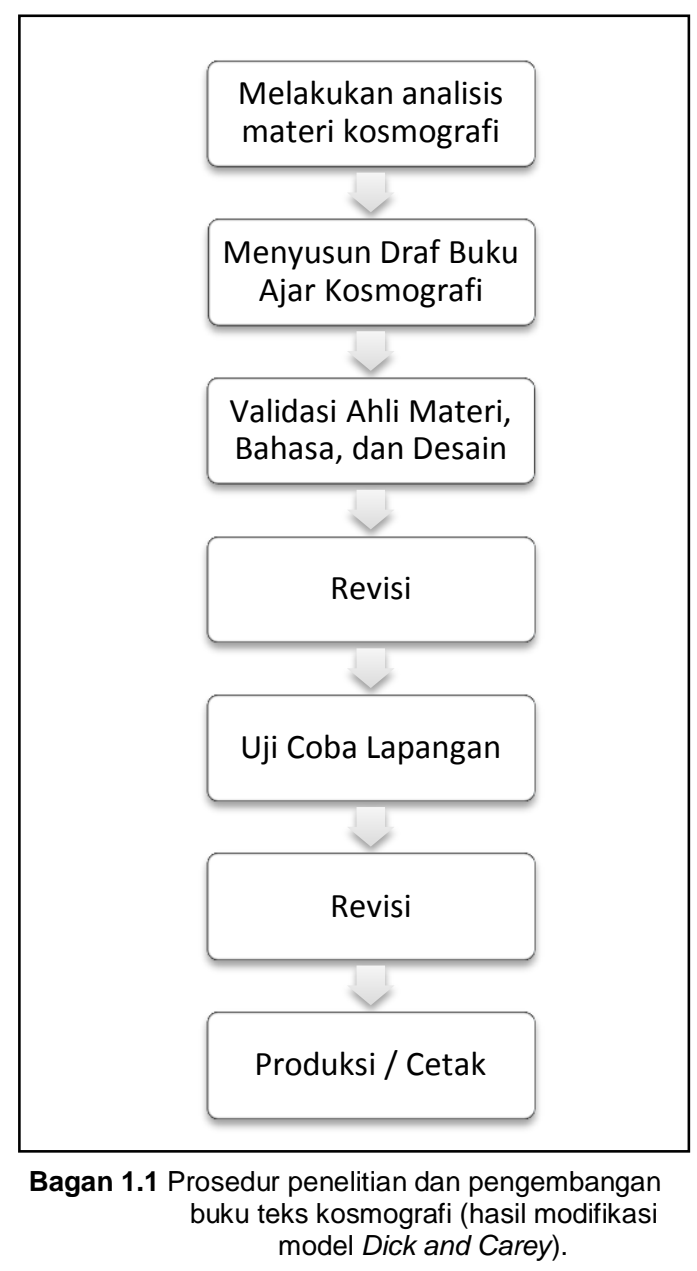

\subsection{Desain Uji Coba}

Tingkat validitas bahan ajar dilakukan melalui validasi dan uji coba lapangan. Kelayakan buku teks diketahui melalui hasil tanggapan ahli dan mahasiswa melalui saran dan tanggapan dalam angket.
Indikator utama kelayakan bahan ajar tersebut mengacu pada standar yang ditetapkan Badan Standar Nasional Pendidikan (BSNP) yang menetapkan empat kriteria utama yaitu: (1) isi/materi disajikan dengan kebenaran konsep, fakta, data, kerunutan, cakupan, akurasi, kemutakhiran, dan mengandung wawasan kontekstual, (2) memenuhi standar objek studi formal dan material, (3) penggunaanmedia gambar, grafik, dan peta (4) kebenaran penggunaan bahasa.

Instrumen yang digunakan untuk mengumpulkan data dalam penelitian ini berupa angket. Angket di desain dengan 3 katagori yaitu: desain bahan ajar, materi, bahasa, dan media gambar. Selain itu, angket juga menyajikan pertanyaan tentang pengaruh integrasi ayat Al-Quran dalam bahan ajar kosmografi.

Teknik analisis data dalam penelitian ini menggunakan analisis deskriptif. Analisis tersebut digunakan untuk mengolah data yang diperoleh dalam bentuk analisis skor kriteria minimum menggunakan skala likert. Penggunaan skala likert untuk menyajikan data frekuensi respon penerimaan mahasiswa terhadap produk bahan ajar kosmografi setelah dikembangkan. Untuk mempertegas hasil skala perhitungan juga dilakukan dengan cara persentase (\%).

Aspek atau komponen yang akan dianalisis terdiri dari: desain bahan ajar, materi, bahasa, media gambar serta muatan ayat Al Quran. Kemudian, hasil tanggapan mahasiswa dari angket diolah menggunakan rumus presentase berikut: 
Persentase

$=\frac{\left.\sum \text { (keseluruhan skor jawaban angket }\right)}{n \times \text { bobot terting gi } x \text { jumlahresponden }} \times 100 \%$

Keterangan:

$\mathrm{n}=$ jumlah seluruh item angket

Selanjutnya hasil perhitungan dideskripsikan dengan tabel katagori interval untuk menunjukkan posisi hasil dengan tanda garis tebal (D) (Sugiyono: 2010), misalnya 110 dapat diarsir pada batas sebagai berikut:

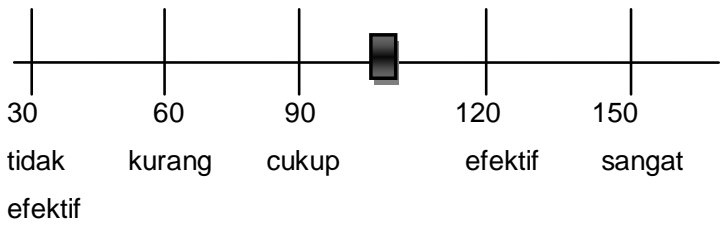

Untuk dapat memberikan makna dan pengambilan keputusan digunakan ketetapan sebagai berikut:

Tabel 1. Kualifikasi Bahan Ajar

\begin{tabular}{ccc}
\hline $\begin{array}{c}\text { Tingkat } \\
\text { Pencapaian }\end{array}$ & Kualifikasi & Keterangan \\
\hline $86 \%-100 \%$ & $\begin{array}{c}\text { Sangat } \\
\text { Efesien }\end{array}$ & $\begin{array}{c}\text { Tidak perlu } \\
\text { revisi } \\
\text { Tldak perlu } \\
\text { revisi }\end{array}$ \\
$71 \%-85 \%$ & Efisien & Revisi \\
& Cukup & Revisi \\
$56 \%-70 \%$ & $\begin{array}{c}\text { Efesien } \\
41 \%-55 \%\end{array}$ & $\begin{array}{c}\text { Kurang } \\
\text { Efesien }\end{array}$ \\
& $\begin{array}{c}\text { Sangat } \\
\text { kurang }\end{array}$ & Revisi \\
& Efesien \\
& \\
\hline Sumber: BSNP (Depdiknas), 2006. &
\end{tabular}

\section{Hasil dan Pembahasan}

Uji coba bahan ajar kosmografi berbasis Al Quran dilakukan di Program Studi Pendidikan Geografi Universitas Samudra. Kegiatan ini melibatkan 27 mahasiswa (selaku calon pengguna produk). Mahasiswa yang dipilih bukan mahasiswa unggulan atau yang dikhususkan. Mahasiswa yang dilibatkan dalam uji coba merupakan mahasiswa yang telah mengambil mata kuliah IImu Alamiah Dasar (IAD) dan sedang mengambil mata kuliah Kosmografi. Hal ini bertujuan untuk medapatkan data yang komprehensif tentang produk yang dikembangkan.

Pada saat uji coba lapangan, data yang diambil meliputi tanggapan mahasiswa terhadap produk bahan ajar kosmografi. Data diambil dengan menggunakan angket yang telah dikembangkan. Angket yang dingunakan terdiri dari beberapa pertanyaan yang dikasifikasi ke dalam kelompok desain, bahasa, konten (materi), muatan kandungan Al-Quran dalam bahan ajar serta keberfungsian media gambar. Data hasil tanggapan mahasiswa terhadap bahan ajar kosmografi disajikan dalam Tabel 2 berikut:

Tabel 2. Rekapitulasi data tanggapan mahasiswa

\begin{tabular}{llccccc}
\hline No & Katagori & $\begin{array}{c}\text { Jumlah butir } \\
\text { angket }\end{array}$ & $\mathrm{X}$ & $\mathrm{Xi}$ & $\%$ & Kualifikasi \\
\hline 1 & Desain & 5 & 843 & 1050 & 81,51 & Efisien \\
2 & Bahasa & 4 & 613 & 840 & 82,52 & Efisien \\
3 & Materi & 5 & 843 & 1050 & 86,41 & Sangat Efisien \\
4 & Gambar & 2 & 363 & 420 & 72,42 & Efisien \\
\hline$\Sigma$ & & 16 & 2659 & 3360 & 80,42 & Efesien \\
\hline \multicolumn{7}{c}{ Sumber: Analisis Data Primer, 2017 }
\end{tabular}


Dari tabel 2 di atas dapat diketahui bahwa tingkat penerimaan produk bahan ajar kosmografi berbasis Al Quran mencapai 80,42 \%. Merujuk pada standar penerimaan produk bahan ajar yang dikembangkan oleh Badan Standar Nasional Pendidikan (2006), produk tersebut dapat dikatagorikan layak.

Skor tertinggi diberikan mahasiswa pada katagori materi yang mencapai $86,41 \%$ (sangat efisien). Menurut responden penyajian dan peng-organisasian materi dalam bahan ajar kosmografi mudah dipahami. Merujuk pada katagori pengembangan kognitif yang dikembangkan oleh Beck dan Mckeown (dalam Purwanto, 2001) konsep yang terkandung dalam bahan ajar kosmografi dapat dikatagorikan valid. Hal ini dikarenakan wacana yang terkandung dalam bahan ajar kosmografi mengandung poin yang jelas (eksplisit). Bahan ajar yang baik harus terhindar dari konsep yang samar-samar/bias sehingga dapat membingungkan pembaca (Greene dan Petty dalam Husen, 1998).

Selain itu, adanya integrasi ayat Al Quran ke dalam materi kosmografi membuat pembaca (mahasiswa) menambah keyakinan kepada Tuhan Yang Maha Esa atas penciptaan alam semesta. Hal ini dibuktikan pada jawaban dalam angket yang diberikan. Sebagian besar responden memberikan skor 5 (sangat efektif) pada aspek integrasi ayat Al Quran dalam bahan ajar kosmografi. Responden menyatakan adanya ayat Al Quran yang menjelaskan tentang alam semesta dan telah dibuktikan oleh kajian sains dewasa ini membuat mereka meyakini kebesaran Tuhan serta menambah keyakinan tentang hancurnya alam semesta di masa akan datang (kiamat). Kondisi tersebut tentu akan meningkatkan kecerdasan spiritual mahasiswa yakni berkepribadian shaleh dengan cara mengungkapkan rasa syukur dan rendah hati (Emmons, 2009). Selain itu, akan membuat mahasiswa menjadi pribadi yang mengagungkan Tuhan setelah mempelajari kosmografi.

Hal tersebut merupakan temuan penting dalam penelitian dan pengembangan ini. Meskipun kecerdasan spiritual sulit diukur dengan berbagai instrument, namun paling tidak pendapat sebagian besar mahasiswa dalam angket, dapat dijadikan tolak ukur bahwa pembelajaran kosmografi yang membahas tentang alam semesta berbasis Al-Quran dapat meningkatkan keyakinan mahasiswa kepada Tuhan Yang Maha Esa.

Dengan adanya bahan ajar kosmogarfi yang diintegrasikan dengan ayat Al Quran akan meningkatkan kecerdasan spiritual mahasiswa. Hal ini dikarenakan mengkaji Al Quran merupakan salah satu cara yang dapat meningkatkan kecerdasan spiritual (Sukidi, 2002). Hal ini sangat penting, guna membebaskan mahasiswa dari pemikiran sekuler. Selain itu, integrasi kandungan Al Quran ke dalam pembelajaran kosmografi, membuat mahasiswa menyadari bahwa ada kekuatan Tuhan yang sangat besar dalam penciptaan alam semesta. Hal ini membuat mahasiswa tidak menjadi pribadi yang sombong.

Kemudian, dari aspek bahasa, responden memberikan skor mencapai $82,52 \%$. Sebagian besar responden 
(mahasiswa) berpendapat bahwa bahan ajar kosmografi yang dikembangkan menggunakan bahasa yang mudah dipahami. Setiap paragraf mengandung ide pokok yang eksplisit (jelas). Setiap paragraf saling terkait dan berkesinambungan dengan paragraf berikutnya. Hal ini dikarenakan penggunaan kalimat dan paragraf dalam bahan ajar kosmografi disesuaikan dengan standar yang ditetapkan oleh Pusat Perbukuan Nasional (2006). Pengorganisasian kalimat dan paragraf dalam buku ajar membuat pembaca memahami dengan mudah konten (isi) materi yang disampaikan. Dreher dan Singer (1996) mengemukakan bahwa isi dan struktur teks bahan ajar yang baik dan jelas idenya akan mudah dimegerti dari pada diorganisasi dengan tidak baik.

$$
\text { Penggunaan bahasa dalam }
$$

bahan ajar sangat penting untuk diperhatikan. Bahasa buku teks yang jelas, singkat, dan sederhana akan lebih memudahkan pembaca dalam menangkap pesan dari konten (isi) buku ajar (Prastowo, 2013). Selain itu, buku ajar kosmografi berbasis AI Quran menggunakan kalimat yang tidak terlalu panjang. Hal ini disesuaikan dengan usia pembaca (mahasiswa). Untuk peserta didik usia setingkat SMA dan mahasiswa kalimat yang digunakan tidak terlalu panjang yakni 25 kata per kalimat dalam satu paragraf terdiri dari tiga sampai tujuh kalimat (Prastowo, 2013; Purwanto, 2001).

Di samping itu, pemilihan kosa kata dalam bahan ajar kosmografi berbasis Al Quran disesuaikan dengan karakteristik mahasiswa. Kosa kata dalam bahan ajar tersebut ditulis sesuai dengan Ejaan Yang Disempurnakan
(EYD). Kosa kata yang digunakan mudah dipahami oleh mahasiswa (Prastowo, 2013: Aksa, 2015). Hal ini yang menyebabkan mahasiswa dapat dengan mudah memahami isi (konten) dari produk bahan ajar.

Kemudian, dari aspek desain, responden memberikan skor $81,51 \%$. Responden (mahasiswa) berpendapat bahwa desain bahan ajar menarik. Cover bahan ajar kosmografi menggambarkan kandungan isi (konten). Keunikan cover bahan ajar sangat penting untuk diperhatikan. Hal ini dikarenakan tampilan cover yang menarik akan membuat pembaca tertarik untuk membaca isi buku ajar secara keseluruhan (Aksa, 2015). Selain itu, lay out bahan ajar memudahkan responden dalam membaca serta memahami konten materi. Menurut responden, ukuran dan jenis huruf yang digunakan tidak terlalu besar dan kecil sehingga memudahkan responden membaca konten (isi) bahan ajar kosmografi. Bahan ajar yang bagus harus didesain dengan lay out yang menarik dan tidak mencolok (Aksa, 2016; Purwanto, 2001).

Dari aspek media gambar, sebagian besar responden menyatakan belum puas dengan sajian media gambar yang terkandung dalam bahan ajar kosmografi. Menurut responden, banyak media gambar yang pewarnaannya kurang serta kecil. Hal ini membuat media gambar tidak dapat berfungsi dengan baik dalam memberikan retensi (daya) ingat terhadap konten (isi) bahan ajar. Namun, apabila merujuk pada rubrik kriteria keberfungsian media gambar yang dikembangkan oleh Duchastel dan Weller (dalam Purwanto, 2001), 
media gambar yang disajikan dalam bahan ajar kosmografi berbasis Al Quran termasuk dalam katagori deskriptif, yakni suatu gambar untuk menjelaskan objek yang asli atau replica dengan proporsi dan perspektif yang benar.

Meskipun demikian, masukan dari responden akan menjadi masukan berarti dalam penelitian dan pengembangan ini untuk merevisi gambar dalam bahan ajar kosmografi berbasis Al Quran. Pada dasarnya bahan ajar yang baik harus dilengkapi dengan media gambar beserta keterangan - keterangan yang berfungsi untuk menguatkan penjelasan konten (isi) bahan ajar (Prastowo, 2013).

Selain menggunakan angket, untuk menilai pemahaman mahasiswa terhadap konten bahan ajar kosmografi yang terintegrasi dengan ayat Al Quran, dilakukan juga tes pengetahuan mahasiswa menggunakan butir soal pada lembar evaluasi. Butir soal yang digunakan disesuaikan dengan muatan konten yang terkandung dalam bahan ajar kosmografi. Butir soal dibuat dalam bentuk esay dengan tingkat analisis yang bertujuan untuk mengukur pemahaman (kognitif) dan analisa mahasiswa.

Hasil test butir soal menunjukkan bahwa rata-rata nilai yang diperoleh mahasiswa dalam menjawab butir soal mencapai $80 \%$. Dari data tersebut dapat disimpulkan bahwa mahasiswa memiliki tingkat pemahaman yang tinggi terhadap konten bahan ajar kosmografi yang dikembangkan. Hal ini menguatkan bahan ajar kosmografi layak untuk digunakan dalam pembelajaran di perguruan tinggi khususnya pada program studi pendidikan geografi.

\section{Penutup}

Hasil penelitian ini dapat disimpulkan bahwa kajian kosmografi tidak bisa dipisahkan dari kandungan $\mathrm{Al}$ Quran. Hal ini dikarenakan banyak sekali ayat Al Quran yang berhubungan dengan alam semesta. Kandungan ilmiah AI Quran tersebut sangat penting untuk diintegrasikan ke dalam bahan ajar kosmografi. Hal ini bertujuan untuk meningkatkan kecerdasan spiritual mahasisiwa.

Selain itu, untuk membentuk lulusan yang bertaqwa kepada Tuhan Yang Maha Esa seperti yang dituangkan dalam tujuan pendidikan tinggi, pembelajaran yang berlangsung pada perguruan tinggi harus menyentuh ranah sikap dan spiritual. Oleh karena itu, produk penelitian dan pengembangan ini berupa bahan ajar sangat tepat untuk digunakan dalam pembelajaran mata kuliah kosmografi pada program studi pendidikan geografi.

\section{Ucapan Terima Kasih}

Penelitian ini didanai penuh oleh Direktorat Penelitian dan Pengabdian Kepada Masyarakat, Kementerian Riset Teknologi dan Pendidikan Tinggi melalui hibah Penelitian Dosen Pemula (PDP) tahun anggaran 2017. Penulis mengucapkan terima kasih atas dukungan dana yang diberikan sehingga penelitian ini dapat dilaksanakan dengan tuntas. 


\section{Daftar Pustaka}

Abdushshamad, M. 2003. Mukjizat IImiah Dalam Al-Quran. Jakarta: Media Eka Sarana.

Aksa, Fl. 2015. Pengembangan Buku Teks Geografi Model Buku World Geography Materi Sumber Daya Alam SMA

Kelas XI. Tesis (tidak diterbitkan). Malang: Program Pasca Sarjana UM.

Aksa, FI. 2016. Development Of Geography Teks Book Model Book World Geography. Jurnal IImiah IImu Sosial, 2(1): 1-9.

Al-Khader, O. A. 2001. The Qur'an and the Universe: from Bing Bang to the Big Crunch (BeirutSaida: Al-Maktabah AlA'sriyyah) pp: 282-283.

Al - Quran Al-Hikam dan Terjemahan, $1426 \mathrm{H}$ Surah Al Anbiyaa ayat 30. Bandung: Diponogoro.

Al - Quran Al-Hikam dan Terjemahan, $1426 \mathrm{H}$ Surah Al-An'am ayat 30. Bandung: Diponogoro.

Al - Quran Al-Hikam dan Terjemahan, $1426 \mathrm{H}$. Surah Adh-Dhariyat ayat 51, Bandung: Diponogoro.

Al - Quran Al-Hikam dan Terjemahan, $1426 \mathrm{H}$. Surah An Naml ayat 61, Bandung: Diponogoro.

Astawa, Ida Bagus. 2013. Pengembangan Kurikulum Geografi Berkearifan Lokal Kebutuhan Bali Sebagai Ekologi Pulau Kecil. Media Komunikasi Geografi, 12 (1).

Dreher, M. J. dan Singer, H. 1990. Friendly texts and text-friendly teacher. Theory Into Practice. Vol. XXVIII, No. 2. 1990.
Eicher, J. David. 2015. The New Cosmos. United Kingdom: Cambride University Press.

Eicher, J and Filippenko, A. 2015. How large is the universe? The New Cosmos: Answering Astronomy's Big Questions. United Kingdom: Cambridge University Press.

Emmons, Robert A. 2009. Is Spirituality an Intelligence? Motivation, Cognition, and the Psychology of Ultimate Concern. The International Journal for The Psychology of Religion. Tersedia online:

https://doi.org/10.1207/S15327582I J R1001_2.

Husen, A.dkk. 1998. Telaah Kurikulum dan Buku Teks. Jakarta: Depdikbud.

Lee, J., \& Catling, S.2016. Some perceptions and practices of English geography textbook authors.International Research in Geographical and Environmental Education.

Mahmood, Khalid. 2011. Conformity to Quality Characteristics of Textbooks: The Illusion of Textbook Evaluation in Pakistan. Journal of Research and Reflections in Education, 5(2): $170-190$.

Murtono. 2005. Pendidikan Sains Dalam Al Quran. Jurnal Pendidikan Agama Islam, 3(2): 163-176.

Murtono. 2015. Perspektif Al- Quran Tentang Astronomi. Jurnal Kaunia,1(1): 22-35.

Purwanto, Edy. 2001. Mengkaji Buku Pelajaran IPS Geografi Untuk Meningkatkan Kualitas Hasil 
Belajar. Jurnal IImu Pengetahuan Sosial, 34 (1): 24-25.

Prastowo, Andi. 2013. Panduan Kreatif Membuat Bahan Ajar Inovatif.Yogyakarta: DIVA Press.

Sani, Abdullah . 2015. Sains Berbasis Al Quran. Jakarta: Bumi Aksara.

Seefeldt, Carol. 1993. Social Studies forPreschool-Primary Child. New York: Macmillan publishing Co.

Sugiyono. 2010. Metode Penelitian Pendidikan (Kuantitatif, Kualitatif, dan R\&D). Bandung. Penerbit Alfabeta.

Sukidi. 2002. Rahasia Sukses Hidup Bahagia Kecerdasan Spiritual Mengapa SQ Lebih Penting daripada $I Q$ dan $E Q$, Jakarta: PT Gramedia Pustaka Utama.

Yani, Ahmad. 2014. Pengantar Kosmografi. Yogyakarta:

Penerbit Ombak. 